\title{
INTRODUKSI ALAT PENGERING HYBRID PADA KELOMPOK JARING APUNG DI DESA SIKAKAP, KEC. SIKAKAP, KAB. KEPULAUAN MENTAWAI
}

\section{INTRODUCTION OF HYBRID DRYER TO KELOMPOK JARING APUNG IN SIKAKAP VILLAGE-SIKAKAP DISTRICT, REGENCY OF KEPULAUAN MENTAWAI}

\author{
Alhapen Ruslin Chandra ${ }^{1 *}$, Andasuryani ${ }^{2}$, Yudhytia Wimeina ${ }^{1}$ \\ ${ }^{1}$ Jurusan Administrasi Niaga, Politeknik Negeri Padang, Kampus Limau Manis, Padang 25163, \\ Indonesia \\ E-mail: alhapen@polinpdg.ac.id, yudthytia@gmail.com \\ ${ }^{2}$ Jurusan Teknik Pertanian Universitas Andalas, Kampus Limau Manis, Padang 25163, Indonesia \\ E-mail: andasuryani@fateta.unand.ac.id
}

\begin{abstract}
ABSTRAK
Desa Sikakap berada di Kecamatan Sikakap, Kabupaten Kepulauan Mentawai yang terletak di pulau Pagai Utara dengan potensi perikanan yang sangat tinggi. Salah satu sumber penghasilan bagi masyarakat di desa tersebut adalah usaha ikan kering asin. Selama ini proses pengeraingan hanya mengandalkan energi matahari saja. Namun, karena letaknya yang dikelilingi lautan, maka iklim di wilayah ini sangat dipengaruhi oleh angin musim. Curah hujan berkisar antara 2.500 $4.700 \mathrm{~mm} /$ tahun dengan jumlah hari hujan antara 132 - 267 hari hujan per-tahun. Oleh sebab itu perlu diupayakan adanya teknologi pengeringan dalam mengatasi tingkat curah hujan yang tinggi tersebut. Disamping itu, dalam pengelolaan organisasi khalayak sasaran yang bergabung dalam Kelompok Jaring Apung (KJA) Selat Sikakap dan KJA Saruso Mudo, perlu ditingkatkan kemampuan anggotanya agar dapat menjalankan usaha dengan baik. Melalui program IbM, tim pengabdian melaksanakan kegiatan (1) pembuatan alat pengering hybrid dan evaluasi kinerja alat, (2) introduksi alat ke mitra, dan (3) melakukan pelatihan tentang tata kelola organisasi, pembukuan dan pemasaran. Hasil kegiatan menunjukkan bahwa mitra sangat terbantu dalam melakukan usaha produksi ikan asin dengan adanya alat pengering hybrid. Alat pengering hybrid yang diintroduksikan memiliki ukuran $220 \mathrm{~cm} \times 90 \mathrm{~cm} \times 100 \mathrm{~cm}$ (p x 1 x t) dengan sumber energi matahari dan gas Liquified Petroleum Gas (LPG). Disamping itu, melalui kegiatan ini terjadi peningkatan pengetahuan dan keterampilan kelompok KJA dalam hal tata kelola organisasi dan pengelolaan keuangan serta strategi pemasaran usaha.
\end{abstract}

Kata kunci: Alat pengering hybrid, Ikan kering asin, Organisasi, Pemasaran.

\section{ABSTRACT}

Sikakap Village is in Sikakap District, Regency of Kepulauan Mentawai located on the island of North Pagai with a very high fishery potential. One of the activities undertaken by the community as a source of income in the village is salted dried fish business. However, the process to produce the salted dried fish only relies on solar energy. Due to its location which is surrounded by oceans, the climate in this region is strongly influenced by the wind season. Rainfall ranges from 2,500 - 4,700 $\mathrm{mm} /$ year with the number of rainy days between 132 - 267 rain days per year. Therefore, there should be a drying technology in overcoming the high rainfall level. In addition, capabilities of to govern organization of communinity who joint Kelompok Jaring Apung (KJA) Selat Sikakap and KJA Saruso Mudo should be improved to run the business properly. Through the IbM program, team carries out activities: (1) manufacture of hybrid dryers and performance evaluation tools, (2) introduction of tools to partners, and (3) conduct training on organizational governance, bookkeeping and marketing. The results show that the partners are very helpful in doing the business of salted fish production in the presence of hybrid dryers. The introduced hybrid dryers have a size of $220 \mathrm{~cm} x 90$

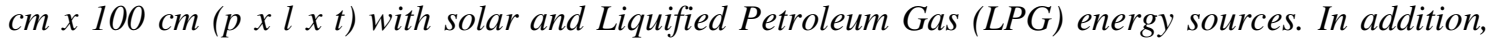
through this activity there is an increased knowledge and skills of KJA groups in terms of organizational governance and financial management as well as business marketing strategies.

Keywords: Hybrid dryer, Salted dried fish, Organization, Marketing. 
PENDAHULUAN

Kabupaten Kepulauan Mentawai merupakan salah satu kabupaten di Propinsi Sumatera Barat yang kaya akan potensi sumber daya alam wilayah pesisir.Kabupaten Kepulauan Mentawai terletak di sisi barat pulau Sumatera yang dipisahkan oleh selat Mentawai. Luas Kabupaten Kepulauan Mentawai sebesar $6.011,35 \mathrm{~km}^{2}$ yang terdiri dari empat pulau besar yang terbentang dari utara ke selatan, yaitu pulau Siberut, pulau Sipora, pulau Pagai Utara, dan pulau Pagai Selatan serta 98 pulau kecil. Secara administratif, Kabupaten Kepulauan Mentawai terdiri atas 10 kecamatan, 43 desa dan 341 dusun (BPS Kab. Mentawai, 2015). Kondisi geografis Kabupaten Kepulauan Mentawai yang berupa daerah kepulauan dengan panjang garis pantai sebesar 1.402,66 $\mathrm{km}$, tentu saja kaya akan sumber daya kelautan dan perikanan. Menurut data BPS Kab. Kep. Mentawai (2015), total produksi perikanan laut di Kabupaten tersebut pada tahun 2014 adalah sebesar 5.278 ton. Jenis potensi ikan yang ada adalah ikan kerapu, kakap, capa, tuna, udang, kembung, selar dan lain-lain. Ikan kerapu merupakan salah satu hasil laut yang menjanjikan karena paling tinggi produksinya, yaitu sebesar 1.182 ton dan juga memiliki nilai ekonomis yang baik dan sangat diminati di pasar internasional.

Potensi kelautan dan perikanan yang besar ini menjadi sumber penghidupan bagi masyarakat yang hidup di wilayah pesisir yang berprofesi sebagai nelayan. Berdasarkan data BPS Kabupaten Kepulauan Mentawai tahun 2015, jumlah nelayan perikanan laut di daerah tersebut pada tahun 2013 adalah sebanyak 2.149 orang yang terdiri dari 1.043 nelayan penuh dan 1.106 nelayan sambilan. Nelayan penuh terbanyak berada pada Kecamatan Sikakap dan Sipora Utara yaitu 148 orang sedangkan nelayan sambilan terbanyak pada Kecamatan Sipora Utara yaitu 208 orang. Pada usaha penangkapan ikan, sebagian besar para nelayan masih menggunakan teknologi penangkapan ikan secara tradisional yaitu menggunakan pancing dan perahu tanpa motor. Hanya sebagian kecil yang menggunakan sarana penangkapan ikan yang berupa perahu dengan motor tempel dan kapal motor.

Desa Sikakap adalah salah satu desa di Kecamatan Sikakap, Kab. Kep. Mentawai yang terletak di pulau Pagai Utara. Desa Sikakap mempunyai garis pantai sepanjang $58.707 \mathrm{~km}$ yang terletak dibagian paling timur Selat Sikakap dan mempunyai luas $22,5 \mathrm{~km}^{2}$ (Bandiyono et al, 2007). Di desa ini, nelayan membentuk kelompok usaha Keramba Jaring Apung (KJA). Usaha KJA di desa Sikakap jumlahnya semakin meningkat tiap tahun dan lebih dari $60 \%$ usaha KJA di Kab. Kep. Mentawai terdapat di desa Sikakap. Saat ini, jumlah usaha KJA di Mentawai sebanyak 90 unit. Menurut Hendrik (2009), 
berkembangnya usaha KJA disebabkan oleh beberapa faktor, seperti potensi perairan yang mendukung baik ditinjau dari kualitas air, ketersediaan pakan dan luasnya lokasi pengembangan usaha.

Kelompok usaha KJA Selat Sikakap dan KJA Saruso Mudo merupakandua kelompok nelayan di desa Sikakap yang melakukan kegiatan budidaya ikan jenis kerapu pada keramba yang terapung di permukaan laut. Kelompok usaha KJA Selat Sikakap diketuai oleh bapak Fazri Ahmadi yang berdiri pada tahun 2012. Sementara itu, usaha KJA Saruso Mudo diketuai oleh bapak Al Aziz dan berdiri tahun 2014.

Kelompok usaha KJA menjual hasil pembudidayaan ikan mereka secara langsung pada penampung ikan. Akan tetapi sejak adanya Peraturan Menteri Kelautan dan Perikanan Republik Indonesia No. 58/PERMEN-KP/2014, metode penjualan langsung seperti ini (transhipment) sudah tidak dapat diandalkan oleh para anggota kelompok pembudidaya ikan kerapu di Sikakap, Kab. Kep. Mentawai. Sebelum adanya peraturan tersebut, para anggota kelompok KJA telah melakukan kegiatan lain selain pembudidayaan ikan kerapu, yaitu pengolahan ikan menjadi ikan kering asin. Sejak berlakunya peraturan tersebut, kegiatan produksi ikan kering asin ini menjadi alternatif utama aktivitas ekonomi bagi anggota kedua kelompok usaha KJA sebagai sumber keuangan keluarga.

Sutarni (2013) menyatakan bahwa usaha pembuatan ikan asin merupakan salah satu sumber mata pencaharian sebagian masyarakat di daerah sentra produksi ikan laut. Ikan yang dimanfaatkan oleh kedua KJA ini untuk kegiatan pengolahan ikan adalah ikan segar hasil tangkapan nelayan yang tidak terjual di pasar lokal (Sikakap) atau ikan hasil tangkapan nelayan lokal yang sengaja disisihkan untuk diolah menjadi ikan asin. Dalam hal ini, kedua KJA ini telah melakukan proses pengolahan dan pengawetan ikan. Tuyu et al., (2014) menyatakan bahwa proses pengolahan dan pengawetan ikan merupakan salah satu bagian penting dari mata rantai industri perikanan. Hasil perikanan mudah mengalami kemunduran mutu dan pembusukan yang biasanya terjadi setelah ikan ditangkap. Penanganan yang cepat, tepat dan benar merupakan upaya untuk menjaga mutunya sebelum dipasarkan dan sampai ke tangan konsumen. Ditambahkan oleh Afrianto dan Liviawati (1989) bahwa ikan asin merupakan salah satu produk pengawetan yang banyak terdapat di Indonesia. Pada skala nasional, ikan asin mempunyai kedudukan yang penting, hal ini dapat dilihat bahwa hampir $65 \%$ produk perikanan masih diolah dengan cara penggaraman.

Pada dasarnya, kegiatan pembuatan ikan asin yang dilakukan oleh kedua kelompok KJA ditujukan untuk meningkatkan nilai 
ekonomis beberapa jenis ikan tangkapan nelayan selain ikan jenis kerapu. Dengan demikian, kegiatan ini diharapkan dapat meningkatkan kesejahteraan nelayan di desa Sikakap karena dari sisi sosial ekonomi jauh dari layak. Seperti yang diketahui bahwa Kabupaten Kepulauan Mentawai pada saat sekarang termasuk salah satu daerah tertinggal tahun 2015-2019 dengan peringkat ke 76 dari 122 derah tertinggal di Indonesia, sebagaimana yang ditetapkan dalam Peraturan Presiden Nomor 131 Tahun 2015 tentang Penetapan Daerah Tertinggal Tahun 2015 2019.

Proses pembuatan ikan asin yang dilakukan oleh kedua kelompok KJA ini telah mengikuti prosedur seperti yang dinyatakan oleh Santosa (1998) dan Riansyah et al. (2013) yaitu dimulai dengan membuang sisik dan jeroan ikan kemudian dilakukan pemberian garam dan pengeringan hingga kering di bawah sinar matahari. Produk ikan kering asin yang diproduksi oleh kedua kelompok KJA ini telah menghasilkan ikan kering asin dengan kualitas yang lebih baik dari ikan kering asin yang beredar di pasaran, bahkan di pasar setempat (Sikakap). Hal ini dipengaruhi oleh tingkat kesegaran ikan yang diolah dan penggunaan jenis garam. Tuyu et al., (2014) menyatakan bahwa untuk mendapatkan hasil pengawetan ikan yang bermutu tinggi diperlukan perlakuan yang baik selama proses pengawetan seperti menjaga kebersihan bahan dan alat yang digunakan, menggunakan ikan yang masih segar, serta garam yang bersih. Rahmawaty et al. (2008); Irianto dan Giyatmi (2009) menyatakan bahwa waktu penggaraman yang dilakukan pada proses pembuatan ikan asin tergantung pada beberapa faktor yaitu ketebalan dan kesegaran ikan, kondisi akhir produk ikan asin yang diinginkan, spesies ikan yang diasinkan, kandungan lemak pada daging ikan, jumlah atau kepekatan garam yang digunakan, kehalusan, dan kemurnian garam,serta suhu penyimpanan pasca pengeringan ikan asin. Selanjutnya, dijelaskan oleh Assadad dan Utomo (2011) bahwa penggunaan garam untuk pengolahan ikan adalah sebagai pengawet, penambah cita rasa maupun untukmemperbaiki penampilan tekstur daging ikan.

Walaupun kualitas ikan asin yang dihasilkan oleh kedua kelompok mitra ini cukup baik, namun proses produksi pembuatan ikan asin yang dilakukan tidak dapat berjalan secara berkala atau terusmenerus. Ada beberapa faktor kendala yang cukup signifikan untuk kedua kelompok ini dalam melakukan kegiatan pengolahan ikan menjadi ikan kering asin sebagai kegiatan rutin mereka. Salah satunya adalah faktor cuaca. Proses pengeringan yang dilakukan masih sangat bergantung pada intensitas cahaya matahari, sementara curah hujan di Sikakap terbilang cukup tinggi. Sesuai dengan 
letaknya yang dikelilingi lautan, maka iklim di wilayah ini sangat dipengaruhi oleh angin musim. Curah hujan berkisar antara 2.500 $4.700 \mathrm{~mm} /$ tahun dengan jumlah hari hujan antara 132 - 267 hari hujan per-tahun. Sementara itu kondisi udaranya selalu panas dan lembab. Sedangkan kondisi suhu berkisar antara $22^{\circ}-32^{\circ} \mathrm{C}$ dengan kelembaban 82 $85 \%$.

Disamping itu, kedua kelompok usaha KJA ini dikelola secara tradisional dan sangat sederhana. Keuntungan dan kerugian usaha tidak dapat diketahui dengan baik karena pencatatan atau perhitungan laba dan rugi dilakukan tidak secara kontinyu sehingga tidak dapat dipedomani. Perhitungan laba dan rugi usaha hanya berdasarkan pada perkiraan saja. Pembagian kerja antara anggota kelompok seperti pemberian pakan dan perawatan ada dilakukan, namun tidak terlaksana dengan baik.

Berdasarkan kepada permasalahan yang dihadapi oleh kelompok KJA Selat Sikakap dan KJA Saruso Mudo dalam melakukan usahanya, maka melalui program pengabdian ditawarkan solusi berupa penyediaan teknologi tepat guna yaitu alat pengering hybrid, pelatihan tata kelola organisasi dan pembukuan serta strategi pemasaran. Tujuan kegiatan ini adalah membantu kelompok KJA dalam mengenal, memahami dan mengaplikasikan teknologi pengeringan menggunakan alat pengering hybrid, memahami tata kelola organisasi dan strategi pemasaran dalam menjalankan usaha mereka.

\section{METODE PELAKSANAAN}

Pelaksanaan kegiatan pengabdian ini dilakukan dalam tiga tahap, yaitu:

a) Tahap pembuatan alat pengering hybrid, evaluasi kinerja dan analisis ekonomi.

b) Tahap introduksi alat pengering ke mitra.

c) Tahap pelatihan tata kelola organisasi danstrategi pemasaran bagi usaha mitra.

Pelaksanaan kegiatan ini membutuhkan waktu sekitar enam bulan yang dimulai dari bulan Mei sampai Oktober 2017. Pembuatan alat pengering dilakukan di bengkel lokal yang ada di kota Padang. Setelah alat selesai dibuat, dilanjutkan dengan evaluasi kinerja dengan menggunakan ikan selar bentong (Selar crumenophthalmus) yang diperoleh dari nelayan desa Sikakap Kab. Mentawai.Parameter yang digunakan untuk evaluasi kinerja alat pengering adalah suhu dan kelembaban relatif $(\mathrm{RH})$. Analisis statistik yang digunakan adalah $t$-test pada alfa $5 \%$ dan statistik deskriptif yaitu rata-rata dan stándar deviasi. Analisis ini menggunakan Mixcrosoft Excel. Sementara itu, parameter yang digunakan untuk analisis ekonomi adalah biaya pokok pengeringan ikan dan break event point (BEP). Tahap selanjutnya adalah introduksi alat pengering ke anggota kelompok KJA.Tahap pelatihan tata kelola organisasi dan strategi pemasaran dilaksanakan dalam bentuk 
ceramah dan diskusi dengan melibatkan pada cahaya matahari. Bila cuaca cerah anggota mitra. Kegiatan ini dilaksanakan di desa Sikakap Kab. Mentawai pada tanggal 27 Oktober 2017.

\section{HASIL DAN PEMBAHASAN}

\section{a). Evaluasi Kinerja Alat Pengering Hybrid}

Alat pengering hybrid(Gambar 1) memiliki ukuran ukuran $220 \mathrm{~cm}$ x $90 \mathrm{~cm}$ x 100 $\mathrm{cm}(\mathrm{p} \times 1 \times \mathrm{t})$. Komponen alat terdiri dari kerangka, ruang pembakaran (tempat tungku pembakaran), ruang plenum, ruang pengering. Pada ruang pengering terdapat dua buah rak pengering. Untuk mendistribusikan udara panas digunakan blower listrik $2 \frac{1}{2}$ inci 220 volt 250 watt. Alat pengering hybrid merupakan alat pengering yang menggunakan dua sumber energi yaitu energi matahari dan energi dari gas Liquified Petroleum Gas (LPG).

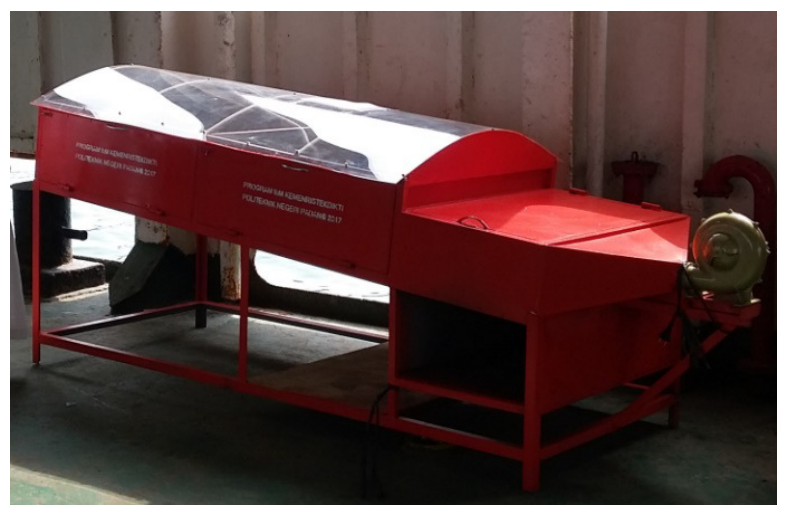

Gambar 1. Alat pengering

Kelebihan dari alat pengering hybrid adalah bahwa mitra dapat melakukan pengeringan sepanjang waktu tanpa tergantung pengeringan dapat dilakukan dengan cahaya matahari saja, jika cuaca tidak memungkinkan untuk melakukan pengeringan dengan cahaya matahari maka dapat digunakan sumber energi dari gas LPG. Basmal et al. (2013) menyatakan bahwa pengeringan dengan menggunakan LPG memiliki kelebihan karena suhu dapat diatur sesuai dengan keinginan serta selama proses pengeringan tidak perlu dilakukan pengawasan secara terus-menerus. Disamping itu kelebihan dari LPG adalah memiliki energi panas yang tinggi yaitu 11 200 kkal dan merupakan bahan bakar yang ramah lingkungan karena mengeluarkan karbondioksida yang lebih rendah dari bahan bakar lainnya.

Hasil evaluasi kinerja memperlihatkan bahwa alat pengering dapat bekerja dengan baik dengan indikator sebaran suhu didalam ruang pengering yang cukup merata. Pada ulangan 1, rata-rata suhu pada rak 1 dan rak 2 berturut-turut adalah $48.21 \pm 3.06{ }^{0} \mathrm{C}$ dan $47.84 \pm 3.20{ }^{\circ} \mathrm{C}$. Pada ulangan 2, rata-rata suhu pada rak 1 dan rak 2 berturut-turut adalah $50.47 \pm 4.91{ }^{0} \mathrm{C}$ dan $50.15 \pm 4.63{ }^{0} \mathrm{C}$. Pada ulangan 3, rata-rata suhu pada rak 1 dan rak 2 berturut-turut adalah $46.94 \pm 3.87{ }^{0} \mathrm{C}$ dan $48.00 \pm 3.91{ }^{0} \mathrm{C}$. Hasil uji statistik ( $t$ test $)$ memperlihatkan bahwa tidak terdapat perbedaan antara suhu rak 1 dengan rak 2 (t hitung $<\mathrm{t}$ tabel pada $\alpha$ 5\%).Hal ini menunjukkan bahwa kecepatan blower yang 
digunakan yaitu $3.59 \mathrm{~m} / \mathrm{s}$ mampu ketertarikannyadengan proses pengeringan mensirkulasikan udara pengeringdengan baik di dalam ruang pengering. Selanjutnya, suhu pengeringan sudah menunjukkan suhu yang sesuai untuk pengeringan ikan seperti yang dinyatakan oleh Abdullah (2003) bahwa suhu pengeringan yang dianjurkan untuk pengeringan ikan adalah $40-50{ }^{\circ} \mathrm{C}$.

Disamping itu, pada pengujian alat juga diperoleh nilai $\mathrm{RH}$ udara pengering yang rendah yaitu berkisar dari $32.89 \pm 8.09 \%$ sampai $45.67 \pm 6.95 \%$. Pada uji coba dengan menggunakan sampel ikan selar bentong diperoleh rata-rata lama pengeringan sebesar $9.42 \pm 2.77$ jam yang mampu menurunkan kadar air ikan sesuai SNI (<40\%) (BSN 2016) yaitu dari $71.14 \pm 1.86 \%$ menjadi $39.98 \pm$ $0.35 \%$ Hasil analisis ekonomi memperlihatkan bahwa biaya pokok pengolahan ikan kering asin dengan menggunakan alat pengering hybrid adalah Rp 23687 / kg dan BEP adalah 537 kg/tahun dengan asumsi keuntungan 10\% dari biaya pokok.

\section{b). Introduksi alat pengering ke mitra}

Kegiatan introduksi alat bertujuan untuk memberikan penjelasan kepada mitra tentangkomponen-komponen alat pengering, cara pengoperasian, perawatan dan pemeliharaan alat serta kelayakan ekonomi. Pada saat introduksi alat ke mitra, terjadi diskusi antara tim pelaksana kegiatan dengan mitra dan mitra menyatakan

ikan menggunakan alat pengering tersebut terutama dari segi keamanan dari lalat. Proses pengeringan ikan dengan menggunakan alat memiliki kelebihan, diantaranya ikan yang dikeringkan terhindar dari lalat terutama lalat hijau. Lalat hijau biasanya akan meletakkan telurnya pada tubuh ikan dan menyebabkan ikan asin hasil pengeringan menjadi rusak seperti adanya ulat.

Keuntungan lainnya bagi kedua kelompok KJA dengan adanya alat pengering hybrid tipe tunneladalah dapat menghasilkan ikan kering asin tanpa terkendala lagi dengan persoalan cuaca sehingga permasalahan pendapatan yang berkurang dari usaha budidaya ikan kerapu dapat diatasi. Pangsa pasar dari ikan kering asin sangat terbuka lebar. Sebagaimana dinyatakan oleh Hutagalung (2014) bahwa ikan kering asing mempunyai prospek yang cukup baik dipasar luar negeri. Kementerian Kelautan dan Perikanan (KKP) mencatat nilai ekspor produk olahan ikan kering mencapai US\$19 juta pada 2010, US\$23 juta pada 2011, pada 2012 mencapai US\$20 juta, dan pada 2013 senilai US\$21 juta. Permintaan pasar ekspor ikan olahan asin lokal mengalami peningkatan cukup tinggi karena produk ikan asin lokal memiliki mutu tinggi dan memiliki standar yang baik. 


\section{c). Pelatihan Tata Kelola Organisasi dan Strategi Pemasaran}

Kegiatan pelatihan tata kelola organisasi dan strategi pemasaran dilaksanakan dengan tujuan untuk memberikan pengetahaun kepada mitra tentang bagaimana mengelola organisasi dengan baik. Pada kegiatan ini, mitra diberikan informasi mengenai pengelolaan keuangan atau pembukuan serta strategi pemasaran yang dilaksanakan dalam bentuk demonstrasi dan ceramah.

Keuntungan yang diperoleh oleh mitra dari pelaksanaan kegiatan pelatihan ini adalah:

a) Peningkatan pengetahuan dan

keterampilan kedua kelompok KJA dalam tata kelola yang meliputi organisasi, job deskripsi, wewenang dan tanggung jawab. Disamping itu, mitra juga mendapatkan pengetahuan bagaimana tata kelola keuangan usaha yang akuntabel dan transparan.

b) Peningkatan pengetahuan bagaimana melakukan strategi pemasaran yang meliputi penentuan produk dan kualitasnya, penentuan segmentasi konsumen yang dijadikan target sasaran produk yang dibuat, strategi penetapan harga, strategi promosi yang efektif, dan strategi distribusi agar produk yang dibuat dapat sampai ke konsumen yang disasar.

Selanjutnya, perubahan kondisi mitra sebelum dan setelah pelaksanaan kegiatan ditampilkan pada Tabel 1 . Beberapa dokumentasi kegiatan diperlihatkan pada Gambar 2.

Tabel 1. Kondisi mitra sebelum dan setelah pelaksanaan kegiatan.

\begin{tabular}{|c|c|c|}
\hline Kegiatan & Kondisi sebelum kegiatan & Kondisi setelah kegiatan \\
\hline \multirow[t]{2}{*}{ Pengeringan } & $\begin{array}{l}\text { Prosess } \\
\text { tergantung pengeringan } \\
\text { cuaca }\end{array}$ & $\begin{array}{l}\text { Proses penegringan tidak } \\
\text { tergantung pada cuaca }\end{array}$ \\
\hline & Adanya gangguan lalat hijau & $\begin{array}{l}\text { Bebas dari gangguan lalat } \\
\text { hijau atau lebih bersih }\end{array}$ \\
\hline Tata kelola & $\begin{array}{l}\text { Belum memahami tata kelola } \\
\text { usaha dan pengelolaan } \\
\text { keuangan yang akuntabel }\end{array}$ & $\begin{array}{l}\text { Peningkatan pengetahuan } \\
\text { dan keterampilan tata kelola } \\
\text { organisasi dan pengelolaan } \\
\text { keuangan yang akuntabel } \\
\text { dan transparan }\end{array}$ \\
\hline Strategis pemasaran & $\begin{array}{lr}\text { Belum } & \text { memahami } \\
\text { bagaimana } & \text { strategi } \\
\text { pemasaran produk } & \\
\end{array}$ & $\begin{array}{l}\text { Peningkatan pengetahuan } \\
\text { bagaimana melakukan } \\
\text { strategi pemasaran }\end{array}$ \\
\hline
\end{tabular}



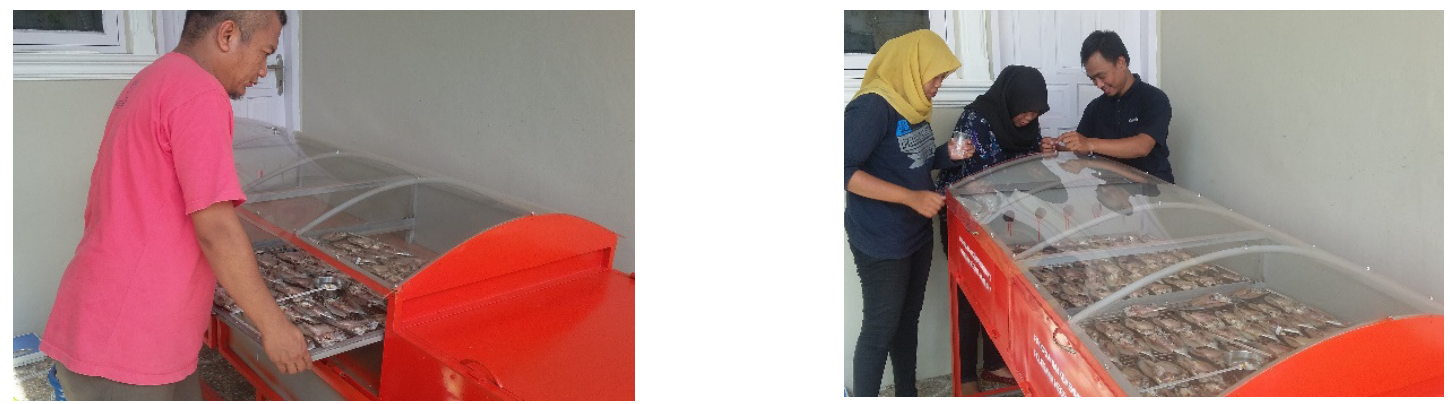

a. Evaluasi kinerja

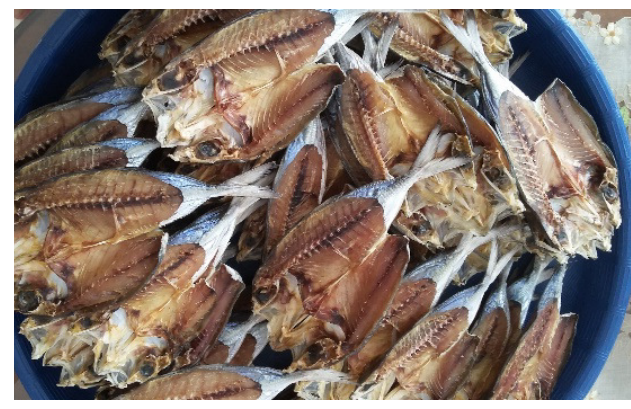

b. Ikan kering yang dihasilkan

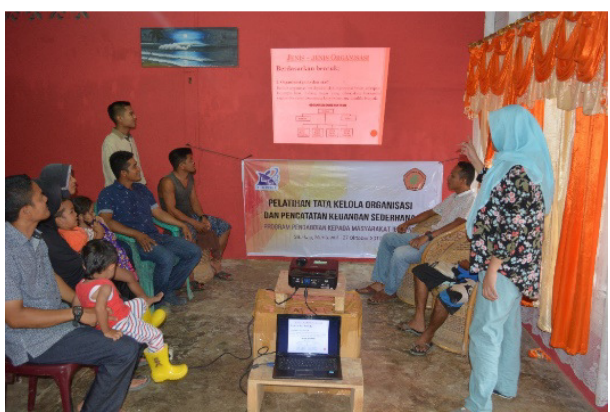

c. Kegiatan pelatihan

Gambar 2. Dokumentasi kegiatan pengabdian.

KESIMPULAN

Kesimpulan dari pelaksanaan kegiatan pengabdian ini adalah

1. Introduksi alat pengering hybrid telah membantu mitra dalam melakukan usaha produksi ikan asin yang selama ini terkendala dengan masalah cuaca.

2. Kegiatan pengabdian ini dapat menambah pengetahuan dan keterampilan kedua anggota kelompok KJA dalam mengeringkan ikan sebagai bentuk transfer teknologi.

3. Adanya peningkatan pengetahuan kelompok KJA mengenai tata kelola organisasi dan pengelolaan keuangan, serta strategi pemasaran produk yang dihasilkan.
SARAN

Saran dari pelaksanaan kegiatan pengabdian ini adalah alat pengering hybrid dapat digunakan untuk proses pengeringan berbagai jenis produk perikanan seperti ikan dan teripang yang prosesnya dapat dilakukan kapan saja atau tidak bergantung pada kondisi cuaca.

\section{UCAPAN TERIMAKASIH}

Penulis mengucapkan terimakasih kepada Direktorat Riset dan Pengabdian Masyarakat Direktorat Jenderal Penguatan Riset, Teknologi, dan Pendidikan Tinggi sesuai dengan Surat Perjanjian Penugasan Pelaksanaan Pengabdian Masyarakat Nomor: 076 / SP2H / PPM / DRPM / 2016, tanggal 3 April 2017 atas sumber dana yang diberikan 
untuk pelaksanaan kegiatan pengabdian dalam skim IbM.

\section{REFERENSI}

Abdullah, K., 2003. Fish Drying Using Solar Energy. Lectures and Workshop Exercises on Drying of Agricultural and Marine Products: Regional Workshops on Drying Technology, Jakarta. 159-191.

Afrianto E dan E. Liviawati. 1989. Pengawetan dan Pengolahan Ikan. Kanisius. Yogyakarta.

Assadad L dan Utomo BSB. 2011. Pemanfaatan Garam dalam Industri Pengolahan Produk Perikanan. Squalen Vol. 6 No.1, Mei 2011. Hal: 26-37.

Bandiyono S, Ngadi, Sudiyono. 2007. Kondisi Sosial Ekonomi Masyarakat di Lokasi COREMAP II Desa Sikakap, Kabupaten Kepulauan Mentawai. Laporan. CRITCLIPI. Jakarta.

Basmal J, Sedayu BB, Utomo BSB. 2013. Kinerja Alat Pengering Mekanis Tipe Vertikal untuk Ikan Petek Leiognathus Sp. JPB Kelautan dan Perikanan Vol. 8 No. 1 Tahun 2013: 34-43

BPS Kabupaten Kepulauan Mentawai. 2015. Kepulauan Mentawai Dalam Angka 2015. BPS Kab. Kepulauan Mentawai, 2015 ISBN: 978-602-355-021-0.

BSN [Badan Standarisasi Nasional]. 2016. Ikan Asin Kering. http://sisni.bsn.go.id/index.php/sni_main/s ni/detail_sni/3106 [diakses 23 Mei 2016]

Hendrik. 2009. Analisis Usaha dan Potensi Pengembangan Keramba Jaring Apung di Desa Sikakap Kabupaten Kepulauan Mentawai Sumatera Barat. Berkala Perikanan Terubuk. Vol. 37 No. 1.
Februari 2009, ISSN No. 0126-4265 hal: 86-92.

Hutagalung SP. 2014. Ekspor Ikan Asin Prospektif.

http://kinciakincia.com/berita/1035/ekspor -ikan-asin-prospektif/ [diakses 27 April 2016].

Irianto HE dan Giyatmi S. 2009. Teknologi Pengolahan Hasil Perikanan. Penerbit Universitas Terbuka. Jakarta. p.7.1-7.51.

Rahmawaty, H., Khotimah, I.K., dan Achmad, J. 2008.Pengolahan ikan kering tenggiri (Scomberomoruscommersonni) berupa "stick" dengan variasi kadar garam dan lama penggaraman. Prosiding SeminarNasional Tahunan V Hasil Penelitian Perikanan dan Kelautan. 16: 19.

Riansyah A, Supriadi A, Nopianti R. 2013. Pengaruh Perbedaan Suhu dan Waktu Pengeringan Terhadap KarakteristikIkan Asin Sepat Siam (Trichogaster pectoralis) dengan Menggunakan Oven. Fishtech. Vo. 2 No. 01. November 2013.

Santoso HB. 1998. Ikan Asin. Penerbit Kanisius. Yogyakarta. 30 pp.

Sutarni. 2013. Faktor-faktor yang Mempengaruhi Produksi Pengawetan Ikan Asin Teri di Kecamatan Labuhan Maringgai Kabupaten Lampung Timur. Jurnal Ilmiah ESAI Vol. 7, No.1, Januari 2013, ISSN No. 1978-6034.

Tuyu A, Onibala H, Makapedua DM. 2014. Studi Lama Pengeringan Ikan Selar (Selaroides Sp) Asin Dihubungkan dengan Kadar Air dan Nilai Organoleptik. Jurnal Media Teknologi Hasil Perikanan. Vol. 2. No.2, Agustus 2014. 